\title{
Olexandr Ponomariov
}

Professor (Technical Sciences) at Pedagogy and Psychology of Social Systems Management Department by the Academician I.A. Zyazyun, National Technical University "Kharkiv Polytechnic Institute", Kharkiv, Ukraine ORCID:0000-0003-4698-2620

E-mail: palex37@ukr.net

\section{Olga Kvasnyk}

$\mathrm{PhD}$ (Pedagogical Sciences), Associate Professor at Pedagogy and Psychology of Social Systems Management Department by the Academician I.A.Zyaziun, National Technical University "Kharkiv Polytechnic Institute", Kharkiv, Ukraine

ORCID: 0000-0001-9911-7337

E-mail: kvasnikov@ukr.net

\section{Yuliia Chala}

PhD (Psychology), Associate Professor at Pedagogy and Psychology of Social Systems Management Department by the Academician I.A. Zyaziun, National Technical University "Kharkiv Polytechnic Institute", Kharkiv, Ukraine E-mail: ju.chalaya@gmail.com

\section{PHILOSOPHICAL AND ANTHROPOLOGICAL BASES OF THE LEADERSHIP'S PHENOMENA}

Abstract: The significant complication of public life and the general increase in the level of educational and qualification training for a wide range of people change the conditions for leadership influence on them and achieve its desired effectiveness. This circumstance significantly enhances the need for a philosophical understanding of the essence of the leadership phenomenon, its role and capabilities. Satisfaction of such need requires a deep analysis and comparison of manifestations in leadership both universal and specific leadership principles. For the successful implementation of this analysis, it is advisable to use the ideas and provisions of philosophical anthropology. They allow us to determine the essence and purpose of the personality of the leader and the conditions for their rational use to satisfy the aspirations and interests of the society and the leader himself. Knowledge of the philosophical anthropology basics can help the leader choose the appropriate ways and means to effectively influence people and thus successfully achieve pre-determined goals, satisfy the interests and aspirations of the participants in joint activities.

Key words: philosophical anthropology, leadership, leadership influence, the essence and purpose of the leader, universal and specific leadership principles, aspirations and interests.

\section{Олександр Пономарьов}

кандидат технічних наук, професор, професор кафедри педагогіки і психології управління соціальними системами ім.. академіка I. А. Зязюна, Національний технічний університет «Харківський політехнічний інститут», Харків, Україна

ORCID:0000-0003-4698-2620

E-mail: palex37@ukr.net

(c) Олександр Пономарьов, Ольга Квасник, Юлія Чала, 2018 


\section{Ольга Квасник}

кандидат педагогічних наук, доцент, доцент кафедри педагогіки і психології управління соціальними системами ім.. академіка I. А. Зязюна, Національний технічний університет «Харківський політехнічний інститут», Харків, Україна ORCID: 0000-0001-9911-7337

E-mail: kvasnykov@ukr.net

\section{Юлія Чала}

кандидат психологічних наук, доцент кафедри педагогіки і психології управління соціальними системами. акад. І.А. Зязюна, Національний технічний університет «Харківський політехнічний інститут», Харків,Україна

E-mail:ju.chalaya@gmail.com

\section{ФІЛОСОФСЬКО-АНТРОПОЛОГІЧНІ ОСНОВИ ФЕНОМЕНУ ЛІДЕРСТВА}

Анотація: Істотне ускладнення суспільного життя й загальне підвищення рівня освітньо-кваліфікаџійної підготовки широкого загалу людей змінює умови лідерського впливу на них і досягнення його бажаної ефективності. Ця обставина помітно посилює потребу філософського осмислення сутності самого феномену лідерства, його ролі й можливостей. Задоволення такої потреби вимагає глибокого аналізу $і$ зіставлення проявів у лідерстві як загальнолюдських, так специффічно лідерських витоків. Для успішного здійснення иьього аналізу доцільно використовувати ідеї й положення філософської антропології. Вони дозволяють визначити сутність і призначення особистості лідера та умови раціонального їх використання заради задоволення прагнень та інтересів соиіуму й самого лідера. Знання основ філософської антропології може допомагати лідерові обирати доиільні шляхи $i$ засоби ефективного впливу на людей $i$ завдяки цьому успішно досягати заздалегідь визначених ијілей, задовольняти інтереси $i$ прагнення учасників спільної діяльності.

Ключові слова: філософська антропологія, лідерство, лідерський вплив, сутність і призначення лідера, загальнолюдські та суто лідерські начала, прагнення та iнтереси.

\section{Александр Пономарев, Ольга Квасник, Юлия Чалая ФІЛОСОФСКО-АНТРОПОЛОГИЧЕСКИЕ ОСНОВЫ ФЕНОМЕНА ЛИДЕРСТВА}

Аннотация: Существенное усложнение общественной жизни и общее повыщение уровня образовательно-квалификационной подготовки широкого круга людей меняет условия лидерского влияния на них и достижения его желаемой эффективности. Это обстоятельство заметно усиливает потребность философского осмысления сущности самого феномена лидерства, его роли и возможностей. Удовлетворение такой потребности требует глубокого анализа и сопоставления проявлений в лидерстве как общечеловеческих, так специфически лидерских начал. Для успешного осуществления этого анализа целесообразно использовать идеи и положения философской антропологии. Они позволяют определить сущность и назначение личности лидера и условия раџионального их использования для удовлетворения стремлений и интересов социума и самого лидера. Знание основ философской антропологии может помочь лидеру вы- 


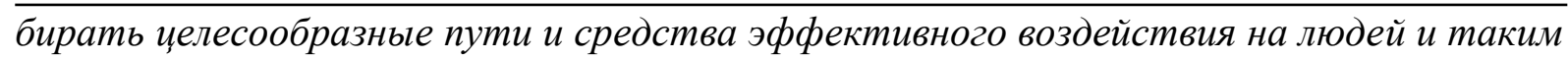
образом успешно достигать заранее определенных целей, удовлетворять интересы и стремления участников совместной деятельности.

Ключевые слова: философская антропология, лидерство, лидерский влияние, сущность и назначение лидера, общечеловеческие и чисто лидерские начала, стремления и интересы.

Problem solving in general and its connection with important scientific or practical tasks. The leadership phenomenon becomes more and more significant in the organization of social life and in defining of its content and character. This causes a significant interest in its essence and nature, its manifestations and peculiarities of the leaders influence on other people, on their activities, actions and behavior. Much attention is paid to the psychology of leadership, the problems of identifying and developing the leadership potential of a person. However, understanding of the philosophical foundations of the leadership phenomenon becomes of paramount importance. It is about the problem of understanding from the standpoint of the essence of man, his place and purpose in the world. These same issues are forming the basis of the problems of philosophical anthropology as an important and specific industry in the general structure of the knowledge system of this direction.

The value of the philosophical and anthropological approach lies in the fact that it is based on the general principles of understanding the essential nature of man, the meaning of his life and activities. The need for this approach is determined by the nature of the leadership problems. Indeed, the nature of the leader is complex and controversial. On the one hand, he, like any person, has not only a set of positive qualities, but also certain weaknesses, disadvantages, and so on. On the other hand, the status of a leader himself obliges to manifestations (at least public) of his best qualities, charisma as the main factors of influence on people and conquest of their will. Another contradiction in leadership is that the personal aspirations, goals and interests of the leader often do not coincide with the same components of the social nature, whose name and for the sake of which he uses his influence on people, mobilizes their forces and energy. Reflections and hesitations of the leader, his doubts in the process of adopting and implementing responsible managerial decisions, the motives he prefers - all these and many similar circumstances determine the general nature of the problem that is causing our interest.

The need for a profound philosophical understanding of the phenomenon of leadership is conditioned by social needs in the rational use of positive features and its capabilities, overcoming or at least neutralizing its negatives. It fully concerns both the essence of leadership and its various manifestations in specific life situations.

An analysis of the nature, essence and capabilities of leadership from the standpoint of philosophical anthropology allows you to deepen the theoretical positions, especially those relating to its purely human nature and the relationship between the leader and his supporters and followers, with his opponents. After all, the meaning of leadership, the essence and appointment of the personality of the leader are based on a certain set of universal characteristics, and its features are realized in the human environment with the norms and principles adopted in it.

Although philosophy is considered one of the forms of world outlook and in this capacity has a purely theoretical significance, its applied branches can play an important role in the development of the respective spheres of human activity and social life in general. Therefore, the philosophical and anthropological analysis of the phenomenon 
of leadership is aimed at finding ways to enhance leadership potential and leadership education, which ensures the growth of the quality of its impact on people, that is, the quality and effectiveness of their joint activities.

An analysis of recent researches and publications, which initiated the solution of this problem and which the author relies on. The study of the phenomenon of leadership is devoted to a huge number of sources, both monographic and articles in authoritative scientific publications. With regard to the philosophy of leadership and its various aspects , such studies are significantly less. This is due to the predominance of the practical orientation of most works. But the general tendency of philosophical comprehension of the applied spheres of social life and human activity has led to an increase in the attention of serious researchers to many problems of the philosophy of leadership. As an example, we can cite the work of M. Lansky, M. Reznichenko, S. Pazinich, S. Zaevetny, T. Gur, E. Rata, A. Ron-Tas, A. Bunsak, A. Romanovsky, S. Kalashnikova, K. Rodele, W. Schmidt and others. Possibilities for achieving high quality professional activities through transformational leadership are studied by L. Andersen, B. Lotte and their co-authors [10]. Today, much attention is paid to transformational leadership, as evidenced by the publications of such authors as L. Andersen, L. Bro, J. Van Dum, H. Elrekhail, O. Eemagvali, D. Cooper, M. Mumford, D. Oja and others, M. Alveson and D. Carreman analyze the causes of intellectual failure and ideological success in organizing the study of transformational leadership and examine the nature of the influence of ideological and religious factors on the level of its effectiveness [9].

A bit less researchers attention attracts the purely interesting philosophical problems of the phenomenon of leadership. For example, N.S. Gorbacheva, from the standpoint of leadership philosophy, deals with the history of thoughts about the essence of the concept and the methodology of studying the political direction of this phenomenon in a rather detailed way. On her deep conviction, "considering the evolution of ideas about political leadership, it should be guided by the organization practice of a particular society in one or another period of history" [4, p. 19]. This idea is close to understanding leadership through the phenomenon of power, which was investigated by M. Weber, who, by the way, deeply worked out the essence of the phenomenon of charisma. Considering power as one of the main values, the scientist considered charisma as "the quality of the individual, which is recognized as unusual, so that this person is valued as gifted by supernatural, superhuman abilities" [3, p. 139]. Interesting philosophical problems of creative leadership is analyzed by P. Casse [11]

Little is known about the publications in which leadership would be considered from the standpoint of philosophical anthropology, although this very important branch of the system of philosophical sciences which has been developing since ancient times (Aristotle, Epictetus). Problems of the meaning and essence of the man attracted the attention of well-known medieval thinkers (Augustine, Thomas Aquinas), as well as I. Kant, B. Pascal, later systematic presentation of the basic provisions of philosophical anthropology carried out by European, first of all, German thinkers as M. Scheler, G. Plesner, A. Gelen , K. Lorenz, E. Cassierer, P. Landsberg. A worthy contribution to the understanding and development of its main problems belongs to such scholars as M. Buber, M. Berdyaev, A. Voloshin, S. Frank and others.

Today, philosophical anthropology has gained considerable popularity in the Ukrainian philosophical thought. V. Shynkaruk became the recognized founder of the corresponding Ukrainian philosophical school, and his further development was associated with the names of $V$. Tabachkovsky, A. Kanarsky, V. Kremen, M. Popovich, S. Krymsky, I. Bichko, G. Gorak, 
O. Yatsenko and others. The Department of Philosophical Anthropology was founded at the Institute of Philosophy of the National Academy of Sciences of Ukraine.

Ideas and principles of philosophical anthropology are also distributed in the education system. The corresponding textbooks are publishing. In particular, the University of Leiden (the Netherlands) operates a special master's program in philosophical anthropology and philosophy of culture, which deals with fundamental issues concerning the study of man and his interactions.

According to P.S. Gurevich, "philosophical anthropology - not only the field of philosophical knowledge, a certain philosophical direction, but also a specific method of thinking, which fundamentally does not fall under the level of formal or dialectical logic" [5, p. 14]. The history of the philosophical anthropology development analyzed in details by scientist in coauthorship with V.S. Styopin [6].

There is a growing tendency to expand the possibilities of obtaining an appropriate educational level for each person in education and in the philosophy of education. It introduces qualitative changes in its purpose, content and character, in particular, strengthening the positions of philosophical anthropology. Expanding the deep essence and meaning of the changes taking place, I.P. Anosov indicates that along with the transition from elite education to high-quality education for all, there is an increase in the world educational branch of the humanitarian component, the introduction of new human sciences and disciplines $[2, \mathrm{p}$. 115-116]. He also includes the introduction to the scientific treatment of the concept of pedagogical anthropology. However, unfortunately, in our high school, technocracy has become much more widespread, the manifestation of which is the constant reduction of the academic disciplines of the social and humanitarian cycle.
Insufficiently researched aspects of the problem remain the deep development of the philosophical and anthropological foundations of the leadership phenomenon. In particular, they should include the ratio of universal and purely leadership features and personality characteristics of the leader, the nature of the contradictory nature of this phenomenon, understanding of the leader of his role and mission and his social and ontological status, as well as relationships with the world and with other people.

The purpose of the paper is to analyze the philosophical and anthropological aspects of leadership as a complex and contradictory individual and social phenomenon. It is meant to attempt to reveal certain of its contradictions, their main sources and manifestations, as well as to demonstrate the possibility of using the main philosophical and anthropological approaches to increase the effectiveness of identifying potential leaders and to organize and implement an effective system of purposeful development of their leadership potential.

Presenting main material. The subject of the philosophical anthropology study is the nature and essence of man, his being and individual manifestations of his personality in the activities and behavior and relationships with other people. Since the individuality of the leader significantly extent affects not only his own actions and behavior, his attitude to other people and the relationship with them, its meaning can not be understood and deeply realized without a purposeful reference to the principles and provisions of contemporary philosophical anthropology. After all, only with the help of its principles it becomes possible to obtain a holistic view of the identity of a particular leader. Indeed, the philosophical and anthropological basis of its holistic understanding is formed in the process of analysis and awareness of the interconnection of the contradictory individual and social nature and the complex nature of his personality. The manifestation of this essence 
is multifaceted, as evidenced by the difference in the life goals and values of the leader as an individual, the goals and values that he professes in accordance with his leadership status, shared by his supporters, including as a result of purposeful influence on them.

Philosophical and anthropological aspects of the leadership phenomenon concern not only and not so characteristic manifestations of the behavior and behavior of the leader and his influence on his supporters and followers, how to form and improve these features and qualities against the background of the universal development of his personality. Obviously, that almost every leader, like any person, has not only feelings, but experiences. His determination can be combined with doubts, and strong volitional features - with certain human defects. He may feel physical and nervous fatigue, he has a desire to rest, and so on. The leader is also far from indifferent to the public assessment of his actions and behavior, his successes, achievements and failures, including his immediate environment.

Such circumstances require not only a philosophical understanding of leadership as a kind of interesting and important phenomenon, but also an appeal to psychology and ethics, to its sociological and cultural aspects. Only such a systematic approach can bring valuable results that are needed not only for a better understanding of the essence and purpose of leadership, but also for the possibility of its practical use in the education system in identifying potential leaders and further developing their professionalism and raising leadership capacity.

An

extremely

important

anthropological aspect of leadership is the motivation of its activities, including the relationship with other people. It seems obvious that motives can have different meanings, content and character, even a different intensity of manifestation. However, they act as a system of productive factor not only of activities, but also the whole meaning of the leader's life, a source of his sense of happiness and fullness of life. The leading motives of his personality become the goals and objectives of his plans, activities and behavior, actively forming the system of his vital values. They act as a factor that unites the goals, aspirations and interests of the leader with the aspirations and interests of his supporters and society as a whole. Along with the motives of this combination, such an extremely important factor, from the philosophical and anthropological point of view, contributes to the leader's responsibility.

Most researchers of the leadership phenomenon hold that the source and at the same time one of the bright manifestations is the charisma of the leader as a defining feature of his personality. Without denying its importance, we consider it necessary to emphasize the essential role in the success of the leader and in the effectiveness of his influence on people, the level of professional and social competence of the leader and his professionally significant personality traits and qualities. It is precisely in them the biological and social origins of the leader as a man are combined. The contradiction between them appears as a source of complexity and paradoxes, which differ many leaders and manifested in their actions, decisions and behavior, in their way of life and in relationships with people, the nature of communication with them. The paradoxes of charismatic leadership are analyzed in detail by O.G. Romanovsky and O. S. Ponomaryov. In their opinion, "the true manifestation of the paradoxical nature of charismatic leadership is precisely the fact that complex problem situations only enhance the will and ability of the leader, activate his intellectual, physical and mental resources. Thanks to this activation, coupled with a high professional competence and a developed sense of self-confidence, their abilities and capabilities, the leader manages to take at first glance unexpected, but quite 
adequate to the situation that arose, the decision"[8, p. 13].

The contradictions and paradoxes of leadership to a great extent are caused by the collision of the inherited leader at the genetic level of his personality traits and qualities and psychological peculiarities with the acquired in the system of education and in the process of life experience of the norms and rules of social cohabitation. First of all, it is about his moral principles and beliefs about his communicative abilities and the attitude towards people, about his general and professional culture. There was a study conducted into representations about the quality of the personality of a modern charismatic leader at the Department of Pedagogy and Psychology Management of Social Systems of NTU "KhPI". According to respondents, it turned out that the leading qualities of his personality are expedient organization of time and ability to feel the state of play (50\%), which is the embodiment of collective expectations. Depending on the dominance of the personality of the leader of the natural or social origins, his individual style, features and peculiarities of his influence on his environment and other people are formed. Therefore, it is no accident that J. Conger and R. Kanungo analyze the manifestations of the behavioral features of charismatic leadership in the organization and find a reasonable conclusion that it is precisely because of them the people who are their carriers assert themselves as leaders and recognize themselves in environment [12] .

A profound understanding of the essence of the leadership phenomenon is simply impossible without resorting to its philosophical principles, primarily to the analysis of purely human nature of leader personality. Philosophical anthropology, revealing the nature and essence of man, the meaning and purpose of its existence, and distinguishes its defining feature, which is considered to be humanity. It is no coincidence that, comparing the actions of man and other living beings, E. Agazzi notes that "a person assumes his purpose, presents it in advance, and its actions are evaluated by how far they lead to this goal, in the degree of perfection determined by means of these ratings. That is why a person gets the opportunity to use intentional, perfect objects so that some of them can become goals and guides for action". On the deep conviction of the philosopher, "if we reduce the study of a person to the narrow-angle level, we thereby deny it specifically human nature. That is why, philosophy is obliged to continue the study of man by his methods, because it not only restores its rights as a philosophy, but also rehabilitates the specifics of a person, without which all our talks, directed against the "humor" of a person or to protect his rights and dignity, is no more than the instructive rhetoric"[1, p. 35].

Leadership, as a phenomenon, is characterized by the intention of influencing people and power over them. At the same time, each leader as an individual is characterized by the usual features and qualities, although their level of development and the dominance of any of them, not only can differ from these parameters from other people, but in the majority of cases, indeed, are different. Indeed, this distinction makes these individuals the real leaders, forcing other people to voluntarily obey their will and execute their orders and orders, even if they are embodied in the form of advice or request.

One of the essential philosophical and anthropological problem of the leadership phenomenon is directly related to the identification of leadership skills of students and the subsequent development of their leadership potential as one of the important tasks of the education system. Since education, as $P$. Matviyenko rightly emphasizes, "is in reflexive unity with philosophy, then the transformational processes in philosophy must have their educational projection." According to the scientist, "this means that the new philosophical comprehension of the world has a correlation with the new ways of its 
educational" appropriation "of man, the principles of the formation of rationality" [7, p. 93]. Indeed, for a true leader, especially in our complex dynamic time, we have not enough charisma and natural genetic rice obtained at the genetic level. He needs proper education, psychological training, possession of the principles of forming rationality and the ability to properly implement them in their practical activities.

This thesis receives additional justification because the increase of the educational and qualification level of the general population in the further democratization of public life promotes selfawareness and self-identification of people. The result of these processes is more critical attitude to leaders, attempts to analyze the goals of leadership influence on them. Thus, ensuring the proper effectiveness of this influence requires the leader of the development of his professionalism, moralvolitional qualities, logic and conviction judgments. Equally important for him is the understanding of the philosophical and anthropological provisions and principles and its use to ensure an individual approach to each person, especially those who enjoy the authority in his reference audience.

And for this, the leader needs a certain level of general and philosophical thinking culture, profound knowledge of psychology and philosophical anthropology, developed communicative abilities. Understanding that the growth of the educational and qualification level of people and their self-awareness objectively determines both the increase in the number of potential leaders and the strengthening of their leadership features and qualities should be perceived adequately. Moreover, he needs to learn how to interact with other leaders in a rational way, to work out effective ways of influencing them and delegating them certain powers.

Thus, the complication of social existence brings up new demands for leadership, significantly increasing the importance of philosophical and anthropological factors and the need for their careful consideration when choosing a leader the nature of its influence on a particular person or group. Particular importance is his ability to interact and collaborate with other leaders, including them in the hierarchical management system of the organization and in different parts of the joint activities of its employees. At the same time, the leaders of individual microgroups also need to teach the philosophy and management psychology, instill in them the common values of the organization, develop their ability to use an individual approach, ideas and methods of philosophical anthropology.

Conclusions. The complication of social life, raising the level of education and qualification of people put forward new demands on the leader. Their analysis allows for such conclusions. Firstly, ensuring the desired effectiveness of leadership influence on people requires from the leader not only charisma and developed leadership qualities, but also the presence of a clear philosophy of management, a deep understanding of the psychology of human management and their joint activities.

Secondly, the dynamic nature of modern times determines the possibility of successful influence of the leader on other people, primarily on his followers, only on condition that he consistently adheres to them the principles and principles of philosophy of leadership as a reliable methodological basis of his management activities and the pledge of the successful operation and development of the organization managed by him.

Thirdly, leadership as a complex individual and social phenomenon can be understood through the disclosure of this contradictory nature, since its phenomenon as an object of research is located at the intersection of the interests of philosophical anthropology and social philosophy, psychology of personality, psychology of activity and social psychology.

Fourthly, the application of the ideas and provisions of philosophical anthropology 
in the process of studying the leadership phenomenon is appropriate to use in these two directions. The first direction is connected with the disclosure of the general human nature of the leader and the interaction of the corresponding features and qualities with its purely leadership characteristics. The second direction is the knowledge of the leader of the human nature of his followers and the use of this

\section{Список літератури}

1. Агацци, Э. (1989) Человек как предмет философии. Вопросы философии. № 2. C. 24-35.

2. Аносов, I. П. (2003) Сучасний освітній процес: антропологічний аспект. К.: Твім Інтер. 391 с.

3. Вебер, М. (1988) Харизматическое господство. Социологические исследования. № 5. С. 139-147.

4. Горбачева, Н. С. (2015) Методология исследования политического лидерства. Философия права. № 5 (72). С. 18-22.

5. Гуревич, П. С. (1993) Антропологический ренессанс. Феномен человека. Антология. М.: Высшая школа. С. 3-16.

6. Гуревич, П. С. (1994) Философская антропология. Очерк истории. Философские исследования. № 1. С. 114-129.

7. Матвієнко, П. В. Філософська культура: освітні перспективи: за ред. I. Ф. Надольного. Х.: Лівий берег Мачулін Л. I., 2011.292 c.

8. Романовський, О. Г. \& Пономарьов О.С. (2017) Парадокси харизматичного лідерства. Теорія $і$ практика управління соціальними системами. № 1. С. 4757.

9. Alvesson, M. \& Kaerreman, D. (2016) Intellectual Failure and Ideologcal Success in Organizaton Studies: The Case of Transformational Leadership. Journal of Management Inquiry. Vol. 25. Issue 2. P. 139-152.

10. Andersen, L. B. (2018) Achieving High Quality Through Transformational Leadership: A Qualitative Multilevel knowledge to increase the effectiveness of his leadership influence on them.

Prospects for further exploration are associated with in-depth study of the interconnection, interaction and interdependence of the features and qualities of the leader inherited at the genetic level and acquired in the process of social experience and purposeful development of individual leadership potential of person.

Transformational Leadership and Perceived Professional Quality Public Personnel Management.Vol. 47. Issue 1. P. 51-72.

11. Casse, P. (2007) Philosophy for Creative Leadership: How philosophy can turn perople into more effective . [S. p.] : Athena Press. 280 p.

12. Conger, J. A. \& Canungo R. (1994) Charismatic leadership in organization: Perceived behavioral attributes and their measurement. Journal of Organizational Behavor. № 15. P. 439-452.

13. Trevathan W. R. (1987) Human Birth. An evolutionary perspective. N.Y. $438 \mathrm{p}$.

\section{References}

1. Agacci, Je. (1989) Chelovek kak predmet filosofii. Voprosy filosofii. [Man as a matter of philosophy. Questions of philosophy] № 2. S. 24-35. [in Russian]

2. Anosov, I. P. (2003) Suchasnyj osvitnij protses: antropolohichnyj aspekt. [Modern educational process: Anthropological aspect] K.: Tvim Inter. 391 s. [in Ukrainian]

3. Veber, M. (1988) Harizmaticheskoe gospodstvo. Sociologicheskie issledovanija. [Charismatic domination. Sociological research] №5. S. 139-147. [in Russian]

4. Gorbacheva, N. S. (2015) Metodologija issledovanija politicheskogo liderstva. Filosofija prava. [Methodology of political leadership research. Philosophy of Law] № 5 . S.18-22 [in Russian]

5. Gurevich, P. S. (1993) Antropologicheskij renessans. Fenomen cheloveka. Antologija. [Anthropological renaissance. The phenomenon of man. Anthology] M.: Vysshaja shkola. S. 3-16. [in Russian] 
6. Gurevich,

P. S. (1994) Filosofskaja

Ocherk istorii. Filosofskie issledovanija.

[Philosophical anthropology. An outline of

history. Philosophical studies] № 1. S. 114129. [in Russian]

7. Matviienko, P. V. (2011)

Filosofs'ka kul'tura: osvitni perspektyvy [Philo-

sophical Culture: Educational Perspectives]: za

red. I. F. Nadol'noho. Kharkiv: Livyj bereh

Machulin L.I.. 292 s. [in Ukrainian]

8. Romanovs'kyj, O. H.,

Ponomar'ov, O.S. (2017) Paradoksy kharyzmatychnoho liderstva. [Paradoxes of Charismatic Leadership] Teoriia i praktyka upravlinnia sotsial'nymy systemamy. № 1 . S. 47-57. [in Ukrainian]

9. Alvesson, M., Kaerreman,, D. (2016) Intellectual Failure and Ideologcal Success in Organizaton Studies: The Case of Transformational Leadership. Journal of
Management Inquiry. Vol. 25. Issue 2. P. 139-152. [in English]

10. Andersen, L. B.

Achieving High Quality Through Transformational Leadership. A Qualitative Multilevel Analysis of Transformational Leadership and Perceived Professional Quality Public Personnel Management. Vol. 47. Issue 1. P. 51-72. [in English]

11. Casse, P. (2007) Philosophy for Creative Leadership: How philosophy can turn perople into more effective. [S. p.] : Athena Press, 280 p. [in English]

12. Conger, J. A., Canungo R. (1994) Charismatic leadership in organization Perceived behavioral attributes and their measurement. Journal of Organizational Behavor. № 15. P. 439-452. [in English]

13. Trevathan, W. R. (1987) Human Birth. An evolutionary perspective. N.Y. 438 p. [in English]

Стаття надійшла до редколегіï: 13.05.2018 